\title{
INVESTOR DECISION-MAKING \\ IN THE CONTEXT OF THE EFFECTIVE \\ CORPORATE TAXATION
}

\section{Veronika Konečná', Alena Andrejovská}

\footnotetext{
1 Technical University of Košice, Faculty of Economics, Department of Finance, Slovakia, ORCID: 0000-0003-47510959, veronika.konecna@tuke.sk;

2 Technical University of Košice, Faculty of Economics, Department of Finance, Slovakia, ORCID: 0000-0001-59543008, alena.andrejovska@tuke.sk.
}

\begin{abstract}
Mobility of capital and the efficiency of corporate taxation are important terms for investors who are deciding on the allocation of investment. At present, capital mobility is a modern phenomenon that cuts budgets for tax revenues and affects overall employment and economic growth. The corporate taxation principle means the profit is immediately taxed at the shareholders' level and the tax rate of the shareholders is used as a tax rate for investment profits. The aim of the article is quantifying the degree of dependence between the effective rate and the selected microeconomic determinants, which influence the investment decisions of foreign investors. To achieve the aim, we have selected and analyzed the microeconomic determinants that monitored the economic indicators in the companies. In the article, we focused on the leverage effect, the capital intensity, the company's profitability, the share of development and research spending that companies are willing to provide, and the nominal tax rate, which is the most generalized and primary information for investors. Data for the empirical research are from the financial statements of companies listed on stock exchanges, which lead the business activities in the Member States of the European Union. The data comes from the Amadeus database (2018). Through linear regression analysis, we research the impact of microeconomic determinants and effective tax rates over the period 2008 to 2016 . The analysis has confirmed the established hypothesis. The results of the analysis pointed to the profitability of the company as the indicator that most influence the effective tax rate. Increasing it by $1 \%$ will bring down the effective tax rate by $2.451 \%$. The results were confronted with the theoretical theories of many authors who evaluated this relationship.
\end{abstract}

Keywords: Effective corporate taxation, profitability, nominal tax rate, microeconomic determinants, manager decision making.

JEL Classification: $\mathrm{H} 2 \mathrm{O}, \mathrm{H} 21, \mathrm{H} 25$.

APA Style Citation: Konečná, V., \& Andrejovská, A. (2020). Investor Decision-making in the Context of the Effective Corporate Taxation. E\&M Economics and Management, 23(1), 111-120. https://doi.org/10.15240/tul/001/2020-1-008

\section{Introduction}

In the search for an analytical framework for financing and investment location, that is important to follow the tax tracts, which significantly contribute to the important decision of foreign investors. Corporate taxation is an important element of the tax system of European countries and the one of key factors that influence investors of companies in managing and deciding on the location of their investments and business activities. In terms of economic efficiency, tax systems should ideally be "neutral", particularly as regards economic decisions. From this perspective, the location of investments in different countries in the international context should not face markedly different effect levels of taxation. The first and important dimension is a statutory tax rate, 
which is determined by the tax laws. It is the simplest and most affordable way to obtain tax information in country, but it is definitely not decisive. According to Bayer (2011), Gupta, (2007) Clausing (2007) and Mura (2019) it is important to monitor the overall tax burden that represents the size of the enterprise's tax. In other words, it is important to monitor the proportion of taxes paid on the total income or profit of an enterprise in that country. Fundamental changes in the tax systems of the EU have the effect of globalization and digitization of the economy, which significantly increased geographical mobility tax. This has created a competitive environment between tax systems that raises concerns about the level and fairness of tax policies in a global perspective. Despite the more globalized economic environment, corporate taxation is still in the hands of individual European Union countries.

Comparison of tax systems based on statutory rates is insufficient and less efficient. For this reason, an effective tax rate (ETR) is being investigated. ETRs track the construction of the tax base and also play an important role in tax harmonization. Effective tax rates in decision making are not only for investors, but also for politicians, economists and other entities who are trying to create favorable conditions for the inflow of debt into the economy. If the high effective tax rate discourages investors from the decision to choose the country as the target destination, the politicians have to use the effective measures to increase the attractiveness of their country. The results of the research of Clausing (2007), Devereux et al. (2008), Devereux and Griffith $(1998,2003)$ have shown that a higher tax rate increases tax revenue. It is possible to find a negative bilateral relationship between the tax rate and the tax revenue. In relation to investments, there is a negative dependency. The corporate tax rate is higher, the more negative impact on investment is a further increase. Conversely, a reduction in corporate taxes (especially the removal of selective allowances and reliefs) may cause deformation of the business and economic environment. This is confirmed by Johansson et al. (2008), which points out the selective tax support for small businesses is not very effective at global level and in no way leads to an increase in total investment. According to Rosen (1992) these investments are related to negative depending on corporate taxation, through the cost of capital. The effect of the negative dependence between corporation tax and corporate investment is also confirmed by Schwellnus et al. (2008), Arnold et al. (2011) and Vartia (2008), who demonstrated the presence of a negative dependence on the level of the industry but at a minimum. The main factors determining the effective tax rates are company size, debt, asset structure and profitability. Empirical studies show the sensitivity of factors affecting the ETR to a certain level of tax rate. For companies with lower ETR, the most important factors are the company size, intensity of inventory and profitability, while in the case of a higher fiscal pressure, the most important factor is debt (Delgado et al., 2014).

Legal persons use various deductions, tax relief and exemptions from taxes, for example: Austria - interest on loans or debts to third parties; Belgium - investments made to protect the environment; Bulgaria - transactions in shares in public companies; Cyprus - bad debts; Ireland - lotteries and some statecontrolled authorities; Italy - income from buildings used for worship; France - minimum annual corporate tax; Germany - capital gains; Greece - profits from the operation of ships by Greek companies; Latvia - family businesses; Lithuania - received insurance payment; Portugal - received dividends; Luxembourg holding companies; Slovenia - donation etc. (Taxes in Europe, 2018).

\section{Literature Review}

\subsection{Effective Tax Rate}

Dyreng et al. (2008) claims that if there is a gap between the effective and nominal rate, the tax system is not effective. Some companies achieve a high nominal rate and a low effective rate, leading to undesirable consequences of an uneven tax system. The capital structure of the company is a good indicator for investigating dependency on effective tax rates. The way companies manage their financial resources is important in terms of funding. Companies have two options to finance their activities, namely debt financing and equity financing. Debt financing is a cheaper alternative (Ribeiro, 2015). Companies tend to favor debt financing due to the deductibility of interest expense. If the leverage is higher, managers are subject to higher corporate discipline imposed by creditors by adopting restrictive clauses. These 
are restrictions that reduce the scope for taking decisions which do not help maximize the value of the company, but rather seek private benefits. We can expect the companies with a higher leverage to show lower effective tax rates (Kraft, 2014).

\subsection{Determinants of the Effective Tax Rate}

Effective tax rates may also be affected by investment decisions. Study by Hanlon et al. (2010) indicates the investment decisions investors could be to some extent affected by taxes on corporate income. The reason is the uncertainty of the number of tax payments and deductions that must be included in the calculation of the present value of the investment. Richardson and Lanis (2007), Kraft (2014) argue that the tax benefits related to capital intensity, which lead to differences between accounting and tax depreciation will be captured in the deferred component of the effective tax rate. Therefore, the capital intensity will not affect the effective tax rate. The important indicator, with the possibility of influencing an effective tax rate, is the profitability of companies. Gupta and Newberry (1997), Richardson and Lanis (2007), Minnick and Noga (2010) and Armstrong et al. (2012) refer to this indicator as the most significant, because in their studies they found a positive relation between corporate profitability and the effective tax rate. If profitability is determined on the basis of pre-tax income, it is possible to expect higher profits to be taxed with higher taxes. On the other hand (Manzon \& Plesko, 2001; Kraft, 2014), it is believed that profitable firms can more effectively benefit from tax exemptions, as well as tax deductions and concessions, and as a result they show greater tax differences. Companies that are more profitable have lower costs associated with tax administration. Therefore, these companies have more resources to invest in tax planning, which contributes to reducing effective tax rates. An important point of view is research and development spending that concerns investment decisions of companies and contributes to reducing corporate tax rates. There are many fiscal incentives in several jurisdictions that invest in research and development and that supports enable companies to benefit from several tax advantages. That means the R\&D programs are subject to tax rates and credit incentives. According to Ribeiro (2015) both development and research expenditures have, as well as capital intensity, a negative impact on the effective tax rate.

Other indicators that affect the effective corporate tax rate are also important, for example the corporate governance mechanisms. Minnick and Noga (2010) emphasize that the distributed structure is associated with a higher effective rate. Florackis (2008) suggests a positive relationship between managerial ownership and corporate governance. Shareholders with higher participation will benefit more from higher profits. Therefore, they support activities contributing to the reduction of the effective rate of corporation tax (Desai \& Dharmapala, 2006). Graham and Tucker (2006) conclude the companies performing tax management show better credit ratings. Companies conducting tax management are more profitable, with more foreign operations, subsidiaries in tax havens, more investing in R\&D and less debt (Graham \& Tucker, 2006; Lennox et al., 2013).

\section{Data and Methodology}

The aim of the article is to quantify the interdependence between the effective tax rate and selected microeconomic determinants. The effective tax rate reflects the true rate of taxation, affecting the decision-making of investors when it comes to the allocation of investments in EU countries. The selection of indicators was conditional on the theoretical origins of Desai and Dharmapala (2006), Richardson and Lanis (2007), Minnick and Noga (2010), Armstrong et al. (2012) and Gupta (2007), who monitored a large number of determinants influencing the effective tax rate. The level of influence of these factors changes depending on the intensity of the relation between the variables. We use a linear regression. Linear regression was also used by Hsiao et al. (2006) and Boubtane et al. (2013), where:

- explained (dependent) variable:

$\square E T R_{i, t}=$ the effective tax rate $i$ in year $t$;

- explanatory (independent) microeconomic variables:

$N T R_{i, t}=$ the nominal tax rate $i$ in year $t$;

$\square \quad L E V_{i, t}=$ the leverage of the company $i$ in year $t$;

$\square C A P_{i, t}=$ the capital intensity of the company $i$ in year $t$; 
$\square R O A_{i, t}=$ the profitability of the company $i$ in year $t$;

$\square R D_{i, t}=$ the expenditure on research and development of the companies $i$ in year $t$.

Using these variables, the following model was constructed:

$$
\begin{aligned}
& E T R_{i, t}=\beta_{0}+\beta_{1} N T R_{i, t}+\beta_{2} L E V_{i, t}+ \\
& +\beta_{3} C A P_{i, t}+\beta_{4} R O A_{i, t}+\beta_{5} R D_{i, t}+\varepsilon_{i}
\end{aligned}
$$

The ceteris paribus condition applies in the model.

We focused on the ROA indicator, which monitors the return on total assets. It points to the efficiency of using the total capital used in the company as a source of financing. Efficiency leads to the formation of additional capital. The leverage is proportional to equity and debt. Both equity and debt are associated with costs. These costs are included in the ETR calculation. Therefore, it is important for us what the value of the leverage is. That is related to the capital intensity indicator. The last indicator is R\&D spending and its impact on ETR. In many countries, the companies' have tax breaks for R\&D spending or spending are completely exempts from corporate taxation.

These indicators are calculated using input data from the financial statements of companies that realize business activities in the Member States of the European Union. The data comes from the Amadeus database (2018). The data was obtained from the company's financial statements listed on a stock exchange. The selection criterion was geographic location (EU Member States) and the period from 2008 till 2016, when the companies achieve a profit. Another criterion was the main business. The company's main business is projected into the NACE Rev. 2 classification performed by the economic entity. On the basis of the criteria, several hundred companies were generated by the software for the reporting period. We eliminated companies that did not provide all the indicators. After the correction, there was 252 companies. Observations are consistent with the number of companies.

The hypothesis-H1: From a microeconomic perspective, the effective corporate tax rate depends mainly on the profitability of companies.

The answer to our hypothesis is partially provided by Gupta and Newberry (1997), Richardson and Lanis (2007), Minnick and Noga (2010) and Armstrong et al. (2012), who concluded that there is a positive relationship between the profitability of companies and the effective corporate tax rate. On the contrary, authors such as Manzon and Plesko (2001) and Kraft (2014) talk about negative relationship, as

\section{Fig. 1: Average values of leverage (2008-2016)}

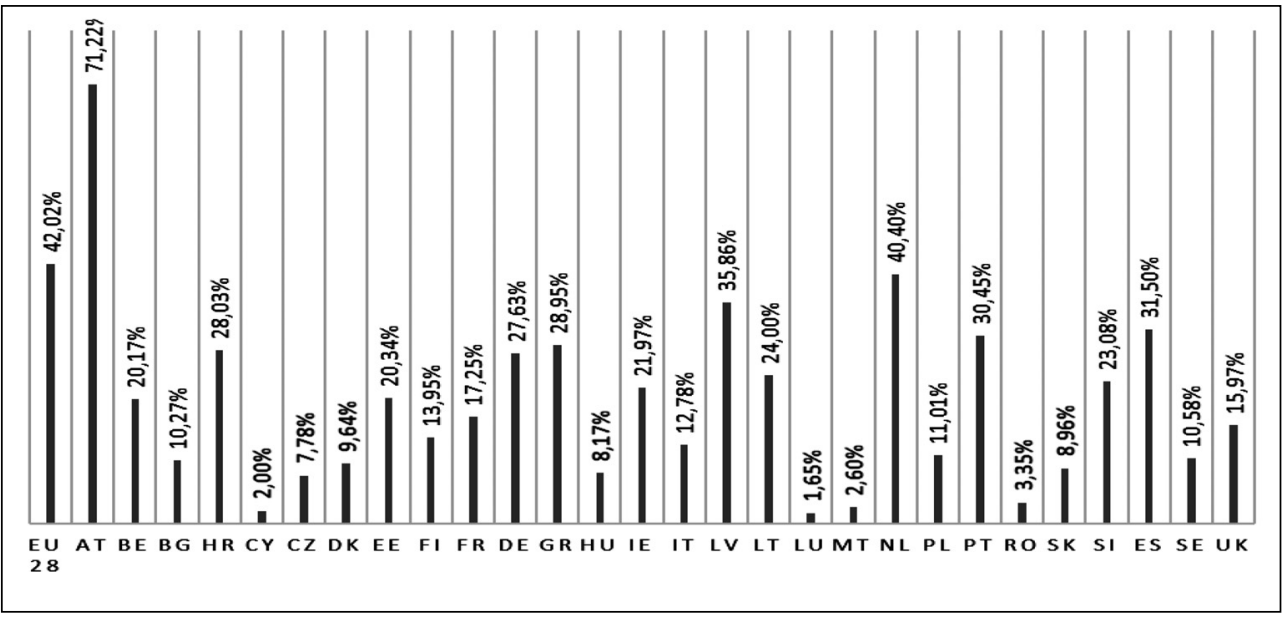


a result of using tax deductions, concessions, tax exemptions, and so on.

\section{Results}

The first determinant is the leverage. The value of this determinant was calculated from data on debt and equity. The average values in the EU Member States indicate the best ratio between debt and equity is in Austrian companies, which is up to $71.22 \%$ (Fig. 1). Austrian companies are more indebted than companies in other countries, perhaps because interest on loans or debts to third parties is a deductible item for them.
The second country is the Netherlands at $40.40 \%$, indicates a higher volume of debt than its equity. Similarly, Latvia has a leverage of $35.86 \%$. On the other hand, the lowest figures are reported by Luxembourg, where this determinant averages only $1.65 \%$. That means a predominance in using debt to finance in Luxembourg companies. Similar results are reported by Cyprus on average by $2 \%$ and Malta by $2.60 \%$. These countries have low corporate tax rates. Money that companies do not pay on corporate tax can be used as equity and does not need to be indebted to third parties. The European average of all member countries is $42.02 \%$.

\section{Fig. 2: Average capital intensity (2008-2016)}

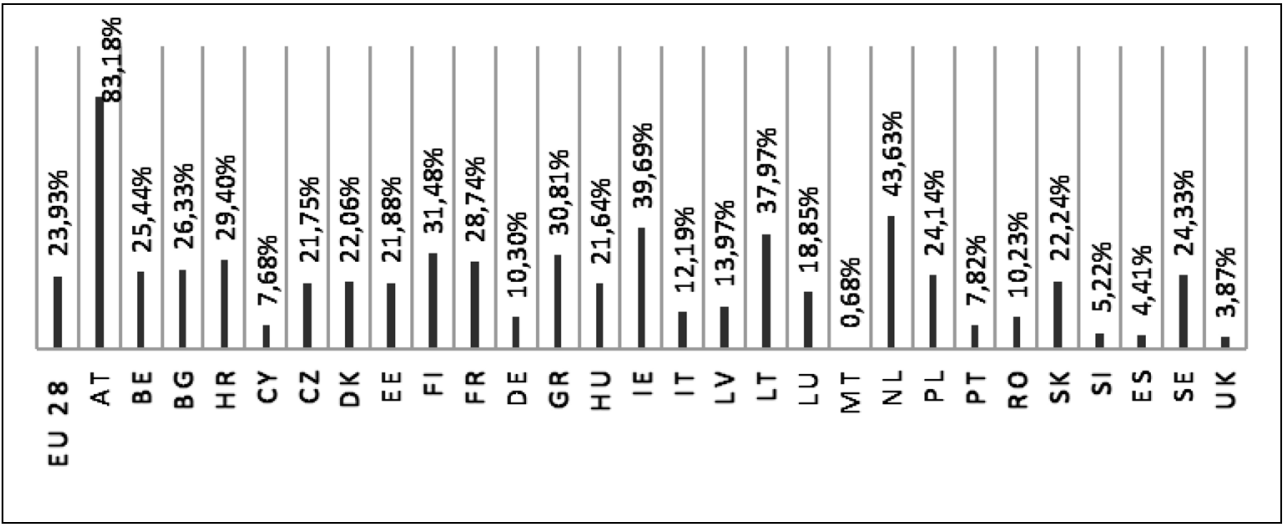

Source: own processing by Amadeus database (2018)

Capital intensity (Fig. 2) indicates the size of the volume of capital that is required to generate the volume of turnover. The average of the indicator is $23.93 \%$ in the EU countries. The highest value is achieved in Austria $(64.65 \%)$. The second is the Netherlands $(42.63 \%)$ and the third is Ireland $(39.69 \%)$, which was 2 percentage points ahead of Latvia. Monitored countries spend a lot more resources per unit of turnover. On the other hand, Malta has a minimum capital intensity of $0.68 \%$. Companies in the United Kingdom $(3.87 \%)$, Spain $(4.41 \%)$ and Slovenia $(5.22 \%)$ also evince a low value.

The company's profitability, expressed by $\mathrm{ROA}$, is the ratio of net profit to total assets. Average value (Fig. 3 ) is at $2.53 \%$. The highest values are again in Austria, where the company's profitability on average up to $58.12 \%$. Other countries were observed at significantly lower levels. Luxembourg reached the second highest value at only $8.63 \%$. Several countries had negative values due to negative business results of the companies. Greece (-13.53\%), Portugal (-1.16\%), Slovenia $(-0.41 \%)$ and Bulgaria $(-0.35 \%)$ achieved the most striking negative results. The average of the profitability indicator is $4.03 \%$ within the European Union.

Descriptive Statistics: The dependent variable, the effective corporate tax rate, had the lowest value in the data at $8 \%$ in Belgium and its maximum at $34 \%$ in Greece. Nominal tax rate values are higher, which was also expected due to the theoretical assumptions that mark the effective rate as more favorable. The minimum 


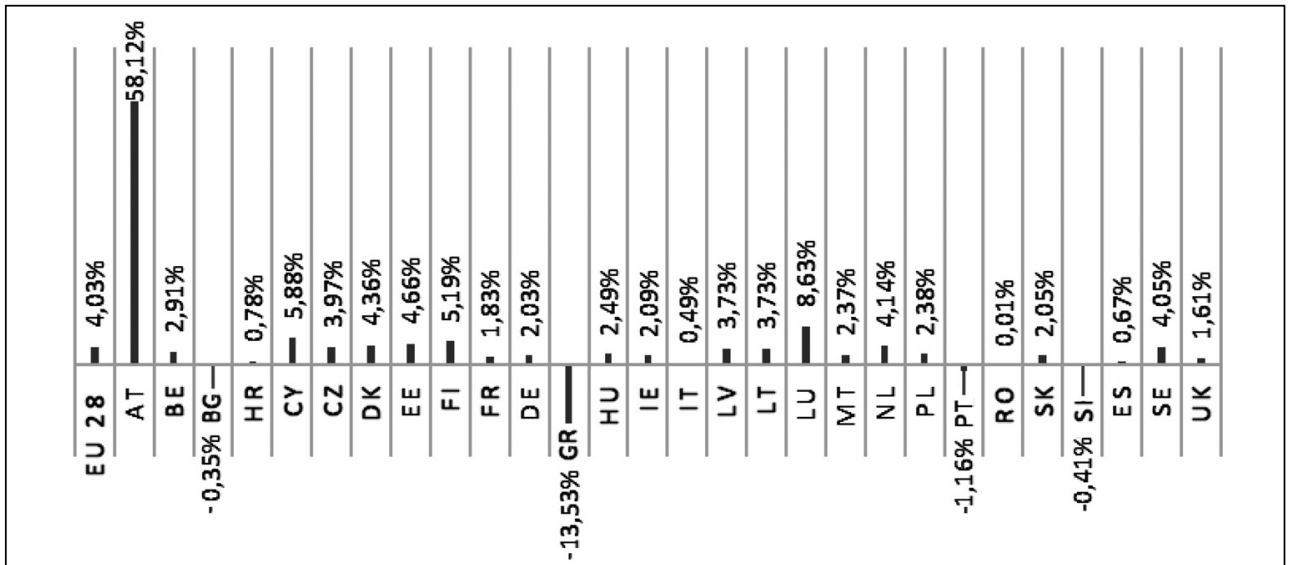

Source: own processing by Amadeus database (2018)

nominal rate is $10 \%$ and a maximum of $35 \%$. The lowest value of companies' leverage is $0.09 \%$. This value was reached in Malta in 2013. On the contrary, the highest value was achieved by Austria $-71.22 \%$. The mean is $16.3 \%$. In the case of capital intensity, the lowest figure is $-2.18 \%$, which belongs to companies in Cyprus in 2016 . The maximum value is $65.2 \%$ and was measured in 2012 in Austria. The profitability of companies is the lowest in Greece in 2016, up to $-35.6 \%$. On the other hand, the highest profitability is achieved by companies in Austria. The highest figure is $65.2 \%$ in 2010 . The average research and development expenditure of the enterprises was low in the monitored period. Despite the tax benefits that many countries offer, companies use their funds for a purpose different from research and development. In the period, companies spent money on R\&D in only nine countries, namely Austria, Belgium, Denmark, Germany, Ireland, Luxembourg, France and Sweden, and the UK. In terms of sharing GDP of countries, expenses are negligible. Companies from countries not mentioned have NA values in the financial statements.

Linear regression analysis tested dependence between selected determinants and effective tax rate (Tab. 1). The result of this analysis are three statistically significant indicators and two statistically insignificant.

The first determinant is the nominal tax rate, which is statistically insignificant. The $\beta 1$ coefficient belonging to this determinant represents a positive effect on the effective tax rate.

\section{Tab. 1: Results of regression analysis}

\begin{tabular}{l|c|c}
\multicolumn{1}{c|}{ Variable } & Estimate & T-value \\
\hline (Intercept) & $1.835 \mathrm{e}-01$ & $11.402^{* * *}$ \\
\hline NTR & $7.038 \mathrm{e}-03$ & 2.120. \\
\hline LEV & $-6.849 \mathrm{e}-05$ & -0.008 \\
\hline CAP & $-1.055 \mathrm{e}-02$ & $-3.162^{* *}$ \\
\hline ROA & $-2.451 \mathrm{e}-02$ & $-3.301^{* *}$ \\
\hline RD & $1.788 \mathrm{e}-05$ & $2.229^{*}$ \\
\hline
\end{tabular}


The leverage of the companies proved to be statistically insignificant. Capital intensity and its impact can be identified as statistically significant on the basis of the results of the analysis and its impact is negative. Increasing corporate capital intensity by $1 \%$ will bring down the effective tax rate by $1.055 \%$. Company profitability (ROA) is statistically significant as capital intensity, which also confirms the $p$-value of 0.00111 . The impact of profitability is negative. Increasing the company's profitability by $1 \%$ will bring down its effective tax rate by $2.451 \%$. Companies' spending on R\&D proved to be statistically significant at a level of 0.05 . The impact of this indicator is positive. Increasing R\&D spending by $1 \%$ will cause an increase of effective tax rate to $0.001788 \%$. It is a very slight increase. The results of the regression analysis have been confirmed by the hypothesis $\mathrm{H} 1$. Profitability is the most significant among selected microeconomic determinants. The coefficient of determination reached 0.8078 , which means the selected function regression explains $80.78 \%$ effective tax rate variability. There was no problem with multicollinearity in the model, that means the model and its variables were correctly specified and the data size is sufficient.

\section{Discussion}

The first determinant included in the model is the nominal tax rate. This indicator is statistically significant and positively affects the effective tax rate. A similar opinion is shared by Dias and Reis (2018), who investigated the relation between the effective tax rate and the nominal tax rate and found a positive dependence. The result of their analysis was the effective rate on average increases of lower value than the nominal rate, which is also confirmed by the analysis we carried out. This is confirmed by other authors (Graham et al., 2016; Rego \& Wilson, 2012; Rego et al., 2009), who argue the companies have the ability to reduce the overall tax to be paid by means of tax management. The leverage and its impact on the effective tax rate has not been confirmed in our analysis, even though the literature describes the negative impact. This relation between the leverage and the effective tax rate was reached by Kraft (2014). Negative impact was also achieved by the capital intensity, which proved to be statistically significant (similarly to Hanlon et al., 2010). However, the increase in capital intensity will reduce the effective tax rate in the company. Reducing the effective rate will be even greater than increasing the capital intensity. The negative relation between effective rate and capital intensity was also found by Richardson and Lanis (2007), who evaluated companies and its capital intensity in the context of profiting from depreciation. They found that the more capital-intensive company can more easily manage taxes, e.g. by postponing depreciation costs. As in the previous case, the impact of companies' profitability on the effective rate was also confirmed. The impact of this indicator is most striking in professional studies. Gupta and Newberry (1997), Richardson and Lanis (2007), Minnick and Noga (2010), and Armstrong et al. (2012) claim that the dependence between profitability and effective rate is positive. However, the result of our regression analysis is the negative impact of profitability on the effective rate, which also appears in the Manzon and Plesko (2001) study. These authors claim the companies which are more profitable have lower costs associated with tax administration. So, they have more funding to invest in the tax planning, which leads to a reduction of effective tax rates. The last observed determinant was spending on research and development, which also proved to be significant. Ribeiro (2015) reported the impact of this indicator on the effective tax rate should be positive, but the literature is not uniform. Our analysis demonstrated positive dependence between spending on R\&D and the ETR. It could be due to the fact that not all countries offer tax exemptions for companies that spend the funding in research and development.

Alvarez et al. (2005), Gries et al. (2012) and Devereux et al. (2004) state the different determinants can generate very different impressions of the severity of the tax regime. The studies confirmed the differences in tax rates have a clear impact on the location of investments. Both the effective tax rate and the tax base will be the key factors for future investors will decision-making about the amount and location of the investment. In other words, investors do not control tax revenues that differ endogenously from output fluctuations and tax base changes due to other determinants. According to the specific tax policy of each country, the correct determination of the tax base is decisive (Egger et al., 2015). In general, it is assumed the increase in corporate tax leads to 
an increase in negative consequences through lower investment and thus to a reduction in returns from the other factors of production, such as capital. Feldstein (1974) and current empirical evidence provided by Dwenger et al. (2011), Arulampalam et al. (2012) and Arachi et al. (2005) state that while small countries with a small share of domestic markets set their effective tax rates to almost zero values, large countries maintain much higher effective tax rates. According to Blechová (2015), the impact of the tax on the return on planned investments is, the higher indicator of effective marginal taxation is, the less attractive country is for potential investors.

\section{Conclusion}

When managers decide on the allocation of their foreign investments and monitor effective tax rates, they consider the characteristics of companies as very important. These are mainly capital intensity, profitability and spending on research and development, which in many countries are exempt from tax. The result of the analysis proved the increase in capital intensity by $1 \%$ will reduce the effective tax rate of $1.055 \%$ and profitability increased by $1 \%$ will reduce the effective tax rate of $2.451 \%$. On the other hand, the positive rate of change was marked by a nominal tax rate, where an increase of $1 \%$ resulted in an increase in effective tax rates of $0.703 \%$. Monitoring nominal tax rates in EU countries is also crucial for managers as monitoring effective tax rates. The article examined the influence of the selected determinants on the effective tax rate, which is a key in the decision making of managers as it expresses the true rate of corporate taxation. The effective tax rate and associated corporate taxation are influenced by a number of factors that need to be further investigated. Some of these factors have already been theoretically outlined, such as the size of companies or number of managers and the shareholder structure of corporations. It is necessary to use other factors in further analyzes which will enrich and bring previously undetected conclusions.

Acknowledgement: This research was supported by VEGA project No. 1/0430/19: "Investment decision-making of investors in the context of effective corporate taxation".

\section{References}

Alvarez, L. H., \& Koskela, E. (2005). Progressive taxation and irreversible investment under uncertainty (CESifo Working Paper No. 1377). Munich: CESifo.

Amadeus database. (2018). Retrieved April 1, 2018, from https://amadeus. bvdinfo.com/version-201845/home. serv?product=AmadeusNeo

Arachi, G., \& Biagi, F. (2005). Taxation, Cost of Capital and Investment: Do Tax Asymmetries Matter? Giornale degli Economisti e Annali di Economia, 64(2-3), 295-321.

Armstrong, C. S., Blouin, J. L., \& Larcker, D. F. (2012). The incentives for tax planning. Journal of Accounting and Economics, 53(1-2), 391-411. http://dx.doi.org/10.1016/j.jacceco.2011.04.001

Arnold, J. M., Brys, B., Heady, C., Johansson, Å., Schwellnus, C., \& Vartia, L. (2011). Tax policy for economic recovery and growth. The Economic Journal, 121(550), F59-F80. http:// dx.doi.org/10.1111/j.1468-0297.2010.02415.x

Arulampalam, W., Devereux, M. P., \& Maffini, G. (2012). The direct incidence of corporate income tax on wages. European Economic Review, 56(6), 1038-1054. http://dx.doi.org/10.1016/j.euroecorev.2012.03.003

Bayer, O. (2011). Vládní daňové predikce: ex ante odhady a ex post hodnocení přesnosti v České republice. Český finanční a účetní časopis, 6(1), 42-54. http://dx.doi. org/10.18267/j.cfuc.96

Blechová, B. (2015). The analysis of dependence fdi flows on the size of corporate income tax rates in EU countries, In: Proc. 7th International Scientific Conference on Finance and Performance of Firms in Science, Education and Practice (pp. 124-136). April 23-24, 2015, Zlin, Czech Republic.

Boubtane, E., Coulibaly, D., \& Rault, C. (2013). Immigration, unemployment and GDP in the host country: Bootstrap panel Granger causality analysis on OECD countries. Economic Modelling, 33, 261-269. http://dx.doi. org/10.1016/j.econmod.2013.04.017

Clausing, K. A. (2007). Corporate tax revenues in OECD countries. International tax and public finance, 14(2), 115-133. http://dx.doi.org/10.1007/s10797-006-7983-2

Delgado, F. J., Fernandez-Rodriguez, E., \& Martinez-Arias, A. (2014). Effective tax rates in corporate taxation: A quantile regression for the EU. Engineering Economics, 25(5), 487-496. http://dx.doi.org/10.5755/j01.ee.25.5.4531 
Desai, M. A., \& Dharmapala, D. (2006). Corporate tax avoidance and high-powered incentives. Journal of Financial Economics, 79(1), 145-179. http://dx.doi.org/10.1016/j. jfineco.2005.02.002

Devereux, M. P., \& Griffith, R. (2003). The impact of corporate taxation on the location of capital: A review. Economic Analysis and Policy, 33(2), 275-292. http://dx.doi.org/10.1016/ S0313-5926(03)50021-2

Devereux, M. P., Griffith, R., \& Klemm, A. (2004). Why has the UK corporation tax raised so much revenue? Fiscal Studies, 25(4), 367-388. http://dx.doi.org/10.1111/j.1475-5890.2004. tb00543.x

Devereux, M. P., Lockwood, B., \& Redoano, M. (2008). Do countries compete over corporate tax rates? Journal of Public Economics, 92(5-6), 1210-1235. http://dx.doi. org/10.1016/j.jpubeco.2007.09.005

Devereux, M., \& Griffith, R. (1998). The taxation of discrete investment choices (IFS working papers No. W98/16). London: Institute for Fiscal Studies.

Dias, P. J. V. L., \& Reis, P. M. G. (2018). The relationship between the effective tax rate and the nominal rate. Contaduría y administración, 63(3), 23-24. http://dx.doi.org/10.22201/ fca.24488410e.2018.1609

Dwenger, N., Rattenhuber, P., \& Steiner, V. (2017). Sharing the burden? Empirical evidence on corporate tax incidence. German Economic Review, 20(4), e107-e140. http://dx.doi.org/10.1111/geer.12157

Dyreng, S. D., Hanlon, M., \& Maydew, E. L. (2008). Long-run corporate tax avoidance. The accounting review, 83(1), 61-82. http://dx.doi.org/10.2308/accr.2008.83.1.61

Egger, P., \& Raff, H. (2015). Tax rate and tax base competition for foreign direct investment. International Tax and Public Finance, 22(5), 777-810. http://dx.doi.org/10.1007/s10797014-9305-4

European Commision. (2018). Taxes in Europe Database. Retrieved April 9, 2018, from http://ec.europa.eu/taxation_customs/tedb/ taxSearch.html

Feldstein, M. (1974). Social security, induced retirement, and aggregate capital accumulation. Journal of political economy, 82(5), 905-926. http://dx.doi.org/10.1086/260246

Florackis, C. (2008). Agency costs and corporate governance mechanisms: evidence for UK firms. International Journal of
Managerial Finance, 4(1), 37-59. http://dx.doi. org/10.1108/17439130810837375

Graham, B., Ashworth, G., \& Tunbridge, J. (2016). A geography of heritage: Power, culture and economy. London: Routledge. https://doi. org/10.4324/9781315824895

Graham, J. R., \& Tucker, A. L. (2006). Tax shelters and corporate debt policy. Journal of Financial Economics, 81(3), 563-594. http://dx.doi.org/10.1016/j.jfineco.2005.09.002

Gries, T., Prior, U., \& Sureth, C. (2012). A tax paradox for investment decisions under uncertainty. Journal of Public Economic Theory, 14(3), 521-545. http://dx.doi.org/10.1111/ j.1467-9779.2012.01547.x

Gupta, A. S. (2007). Determinants of tax revenue efforts in developing countries. (IMF Working Papers, 2007/184), 1-39. Washington: International Monetary Fund. http://dx.doi. org/10.5089/9781451867480.001

Gupta, S., \& Newberry, K. (1997). Determinants of the variability in corporate effective tax rates: Evidence from longitudinal data. Journal of accounting and public policy, 16(1), 1-34. http://dx.doi.org/10.1016/S02784254(96)00055-5

Hanlon, M., \& Heitzman, S. (2010). A review of tax research. Journal of Accounting and Economics, 50(2-3), 127-178. https://doi. org/10.1016/j.jacceco.2010.09.002

Hsiao, F. S., \& Hsiao, M. C. W. (2006). FDI, exports, and GDP in East and Southeast Asia Panel data versus time-series causality analyses. Journal of Asian Economics, 17(6), 1082-1106. https://doi.org/10.1016/j.asieco.2006.09.011

Johansson, Å., Heady, C., Arnold, J., Brys, B., \& Vartia, L. (2008). Taxation and economic growth. National Tax Journal, 49(4), 617-642. https://doi.org/10.1787/241216205486.

Kraft, A. (2014). What really affects German firms' effective tax rate? International Journal of Financial Research, 5(3), 1-19. http://dx.doi. org/10.5430/ijfr.v5n3p1

Lennox, C., Lisowsky, P., \& Pittman, J. (2013). Tax aggressiveness and accounting fraud. Journal of Accounting Research, 51(4), 739-778. http://dx.doi.org/10.1111/joar.12002

Manzon Jr., G. B., \& Plesko, G. A. (2002). The Relation between Financial and Tax Reporting Measures of Income. Tax Law Review, 55(2), 175-195. http://dx.doi. org/10.2139/ssrn.264112

Minnick, K., \& Noga, T. (2010). Do corporate governance characteristics influence tax 


\section{Finance}

management? Journal of corporate finance, 16(5), 703-718. http://dx.doi.org/10.1016/j. jcorpfin.2010.08.005

Mura, L. (2019). Entrepreneurship internationalization - case of Slovak family businesses. Ad Alta: Journal of Interdisciplinary Research, 9(1), 222-226.

Rego, S. O., \& Wilson, R. (2009). Executive compensation, tax reporting aggressiveness, and future firm performance (Working Paper). University of lowa, lowa City.

Rego, S. O., \& Wilson, R. (2012). Equity risk incentives and corporate tax aggressiveness. Journal of Accounting Research, 50(3), 775-810. http://dx.doi.org/10.1111/j.1475679X.2012.00438.x

Ribeiro, A. I. M. (2015). The Determinants of Effective Tax Rates: Firms' Characteristics and Corporate Governance (FEP Working Papers 567). Universidade do Porto, Porto.
Richardson, G., \& Lanis, R. (2007). Determinants of the variability in corporate effective tax rates and tax reform: Evidence from Australia. Journal of Accounting and Public Policy, 26(6), 689-704. http://dx.doi. org/10.1016/j.jaccpubpol.2007.10.003

Rosen, H. S. (1992). Public Finance (3rd ed.). Boston, MA: Irwin.

Schwellnus, C., \& Arnold, J. (2008). Do Corporate Taxes Reduce Productivity and Investment at the Firm Level?: CrossCountry Evidence from the Amadeus Dataset. (Economics Department Working Papers, No. 641), Paris: OECD Publishing. https://doi. org/10.1787/236246774048

Vartia, L. (2008). How do taxes affect investment and productivity?: An industry-level analysis of OECD countries. (Economics Department Working Papers, No. 656), Paris: OECD Publishing. https://doi. org/10.1787/230022721067 